\title{
IbM “PENDEKKAR BIMA" (Pendidikan Kesehatan Kader Dan Remaja \\ Berbasis Masyarakat ) sebagai penguatan kinerja melalui pelatihan pemeriksaan darah di Posyandu Jambu Desa Bogoran
}

\author{
Belian Anugrah Estri ${ }^{1 *}$, Sutarni Djufri ${ }^{2}$ \\ ${ }^{1}$ Universitas 'Aisyiyah Yogyakarta \\ 2Puskesmas Pleret Bantul
}

\section{INFORMASI ARTIKEL:}

\section{Riwayat Artikel:}

Tanggal diterima: 20 Juni 2021

Tanggal direvisi: 25 Juni 2021

Tanggal dipublikasi: 30 Juni 2021

\section{Kata kunci:}

Kader

Lansia

Remaja

\section{ABSTRAK}

Latar Belakang : Tingginya angka lansia akan berpengaruh terhadap tingginya angka penyakit degeneratif khususnya di Daerah Istimewa Yogyakarta yang memiliki populasi lansia tinggi. Di satu sisi, peningkatan angka harapan hidup membawa kebaikan bagi salah satu indikator kesehatan bangsa. Namun di sisi lain, hal tersebut mengarah pada transisi epidemiologi, ditandai dengan pergeseran pola penyakit dari penyakit infeksi menjadi penyakit degeneratif yang berhubungan dengan proses penuaan. Permsalahan : Banyaknya penyakit dgeneratif di masyarakat dan belum ada kader kesehatan yang mampu untuk menggunakan alat kesehatan untuk deteksi dini penyakit degenaratif seperti tensi dan alat cek gula darah. Solusi : Kegiatan ini memaparkan hasil pelaksanaan Iptek bagi Masyarakat (IbM) dalam bentuk pendidikan kesehatan kader dan remaja berbasis masyarakat ) sebagai penguatan kinerja melalui pelatihan pemeriksaan darah di posyandu jambu desa Bogoran. Metode : Kegiatan pemberdayaan masyarakat ini dilakukan dengan pelatihan pada remaja penggunaan tensi dan alat cek gula darah. strategis didalam masyarakat salah satunya peran kader dan remaja yang berkerjasama dalam meningkatkan taraf kesehatan masyarakat, salah satunya dengan pelatihan yang akan dilaksanakan dalam pengabdian ini yaitu pelatihan pemeriksaan gula darah, asam urat, dan kolestrol untuk kader posyandu lansia dan peran seerta remaja di posyandu Jambu di desa Bogoran Trirenggo Bantul. Tujuan : program ini menumbuhkan kepedulian remaja dalam kesehatan di masyarakat salah satunya kesehatan lansia, serta menggerakkan peran aktif dan mandiri dari kader lansia dalam pemeriksaan darah kolestrol, asam urat. Luaran Dihasilkan adalah 10 peserta pelatihan yang terdiri remaja pkk dan kader posyandu lansia yang telah aktif dalam mengikuti pelatihan pemeriksaan darah kolesterol, asam urat, glukosa darah dan hb. Diharapkan dengan partisipasi aktif ini akan menumbuhkan semangat kader dalam memberikan pelayanan di masyarakat serta membentuk kemandirian kader dalam deteksi dini penyakit yang sering dialami lansia. Sebagai tindak lanjut dari kegiatan ini diharapkan mampu memberikan pelayanan dengan baik dan mandiri dalam peningkatan kesehatan lansia, serta melalui etos kerja kader MAU belajar dan harus MAMPU melakukan peningkatan kesehatan di masyarakat salah satunya dengan ketrampilan pemeriksaan darah ini.

Background: The high number of elderly will affect the high rate of degenerative diseases, especially in the Special Region of Yogyakarta which has a high elderly population. On the one hand, the increase in life expectancy is one of the good indicators of the nation's health. But on the other hand, it leads to an epidemiological transition, marked by a shift of the disease pattern from infectious diseases to degenerative diseases associated with the aging process. Problem: There are many degenerative diseases in the community and there are no health cadres who can use medical devices for early detection of degenerative diseases such as blood pressure and blood sugar checks. Solution: This activity describes the results of the implementation of Science and Technology for the Community (IBM) in the form of community-based health education for cadres and youth as performance strengthening through blood examination training at Jambu Integrated Healthcare (posyandu), Bogoran village. Methods: This community empowerment activity was carried out by training the youth on the use of blood pressure and blood sugar checks. One of the strategic roles in the community is the role of cadres and youth who work together in improving community health levels. One of the strategies is implementing the training on various checkups including blood sugar, uric acid, and cholesterol checks for elderly posyandu cadres and the role of youth participation in Jambu posyandu Bogoran Trirenggo Village, Bantul. Objective: This program fosters youth awareness on health in the community, especially the health of the elderly, as well as mobilizing the active and independent role of elderly cadres in checking blood cholesterol, uric acid. Result: The result shows that there are 10 training participants consisting of the youth of PKK and elderly posyandu cadres who have been active in participating in the training of blood tests for cholesterol, uric acid, blood glucose, and HB. It is hoped that this active participation will foster the spirit of cadres in providing services in the community and form the independence of cadres for early detection of the diseases that are often experienced by the elderly. As a follow-up to this activity, it is hoped that they will be able to provide good and independent services in improving the health of the elderly, as well as through the work ethic of cadres of MAU to learn and are able to improve the health of the community including the implementation of blood test. 


\section{Pendahuluan}

Aisyiyah adalah salah satu organisasi otonom khusus Muhammadiyah yang memfasilitasi kegiatan perempuan diberbagai bidang. Struktur organisasi 'Aisyiyah mencerminkan bidang kegiatanya dalam membangun masyarakat islam modern di Indonesia, seperti: syariah Islam, dan dakwah, pemberdayaan perempuan, organisasi kepemudaan, pendidikan, kesejahteraan sosial dan kesehatan.

Tingginya angka lansia akan berpengaruh terhadap tingginya angka penyakit degeneratif khususnya di Daerah Istimewa Yogyakarta yang memiliki populasi lansia tinggi. Di satu sisi, peningkatan angka harapan hidup membawa kebaikan bagi salah satu indikator kesehatan bangsa. Namun di sisi lain, hal tersebut mengarah pada transisi epidemiologi, ditandai dengan pergeseran pola penyakit dari penyakit infeksi menjadi penyakit degeneratif yang berhubungan dengan proses penuaan. Berbagai penyakit tersebut antara lain diabetes melitus, hipertensi, demensia, pembesaran prostat jinak, katarak, dan beragam masalah kejiwaan pada lansia seperti depresi, ansietas, dan gangguan tidur. Kondisi tersebut akan berdampak pada peningkatan kesakitan dan kematian, penurunan kualitas hidup, peningkatan biaya kesehatan, serta kemunculan beragam masalah sosial kemasyarakatan.

Tingginya angka remaja dapat dimanfaatkan dalam proses peningkatan kesehatan dimasyarakat, dimana peran remaja dapat diperdayakan dalam kegiatan masyarakat yaitu posyandu. Diharapkan dengan peran serta remaja di masyarakat akan menumbuhkan kegiatan yang positif didalam diri remaja , sehingga resiko terjerumus dalam lingkungan yang tidak baik akan dapat diminimalisir. Dengan kegiatan positif tersebut remaja dapat membuktikan peran produktifnya dan dapat menunjukan kemasyarakat bahwa remaja tidak selalu dalam kosa kata yang negatif.

Terkait dengan permasalahan tersebut, peran serta oleh generasi muda dalam meningkatkan taraf kesehatan lansia, yaitu dengan ikut serta menyukseskan posyandu lansia di desa masing-masing. Peran strategis didalam masyarakat salah satunya peran kader dan remaja yang berkerjasama dalam meningkatkan taraf kesehatan masyarakat, salah satunya dengan pelatihan yang akan dilaksanakan dalam pengabdian ini yaitu pelatihan pemeriksaan gula darah, asam urat, dan kolestrol untuk kader posyandu lansia dan peran seerta remaja di posyandu Jambu di desa Bogoran Trirenggo Bantul.

\section{Metode Pelaksanaan}

Kegiatan pemberdayaan masyarakat ini dilakukan dengan pelatihan pada remaja penggunaan tensi dan alat cek gula darah. strategis didalam masyarakat salah satunya peran kader dan remaja yang berkerjasama dalam meningkatkan taraf kesehatan masyarakat, salah satunya dengan pelatihan yang akan dilaksanakan dalam pengabdian ini yaitu pelatihan pemeriksaan gula darah, asam urat, dan kolestrol untuk kader posyandu lansia dan peran seerta remaja di posyandu Jambu di desa Bogoran Trirenggo Bantul.

\section{Hasil Pembahasan}

Strategi dan Realisasi pelaksanaan kegiatan pengabdian masyarakat ini dilaksanakan dengan langkah-langkah sebagai berikut :

a. Persiapan

Persiapan dilakukan mulai bulan Oktober terkait perijinan dan konfirmasi dengan ketua kader dan ketua remaja untuk waktu pelaksanaannya, kemudian di sepakati untuk diadakan penyuluhan terkait penyakit degeneratif pada lansia, kemudian dilanjutkan terkait persipan pelatihan kader dan remaja.

Pada tahap ini, akan diadakan penyuluhan pada tanggal Rabu 18 Oktober 2018 terkait penyakit degeneratif pada lansia kepada, lansia kader dan remaja. Alat dan bahan yang diperiapkan meliputi, alat tulis, leflet power point, tempat, serta doorprize. Dalam pelaksanaan ini dilakukan bersamaan dengan posyandu lansia yang rutin dilakukan setiap bulannya.

Hasil kunjungan dan diskusi dengan ketua kader, didapatkan kesepakantan akan dilakukan pelatihan pemeriksaan darah ( asam urat, glukosa darah, hb dan kolesterol pada bulan November

*Korespondensi penulis.

Alamat E-mail: belianestri@unisayogya.ac.id 
minggu pertama yaitu tanggal 4 November 2017. Persiapan alat sudah tersedia , 2 alat pemeriksaan GCHb dan 2 alat GCU, handscun 2 box, anset, vaccinopen, swab alcohol, tissue, 2 boks strip asam urat, 2 boks strip glukosa darah , 2 strip hb, 2 boks stik kolesterol.

Setelah dilakukan pelatihan akan dilakukan pendampingan langsung pada kader yang sudah terlatih dalam meakukan pemeriksaan. Rencana pendampingan (RTL) akan dilakukan pada tanggal 18 November 2017 sesuai dengan jadwal tetap dilaksanakannya posyandu lansia. Dalam hal ini kader lansia maupun remaja sudah mandiri dalam melakukan pemeriksaan darah hb, glukosa, asam urat, dan kolesterol.

Dalam prosesnya yang akan dilibatkan dalam pelatihan adaah kader posyandu lansia sebanyak 6 kader dan kader posyandu remaja sebanyak 4 kader. Hal ini telah disepakati dengan ketua kader dengan harapan bahwa kader kan mandiri dan remaja akan lebih pro aktif lagi terjun kemasyarakat. Melalui pelatihan ini juga kader harus mau dan mampu dalam melakukan pemeriksaan darah secara tepat dan benar. Kader juga mampu dalam memberikan konseling serta menginterprestasikan hasil dalam pemeriksaan yang sudah dilakukan.

Pentingnya pelatihan ini dilakukan dikarenakan tingginya angka lansia akan berpengaruh terhadap tingginya angka penyakit degeneratif khususnya di Daerah Istimewa Yogyakarta yang memiliki populasi lansia tinggi. Di satu sisi, peningkatan angka harapan hidup membawa kebaikan bagi salah satu indikator kesehatan bangsa. Namun di sisi lain, hal tersebut mengarah pada transisi epidemiologi, ditandai dengan pergeseran pola penyakit dari penyakit infeksi menjadi penyakit degeneratif yang berhubungan dengan proses penuaan. Berbagai penyakit tersebut antara lain diabetes melitus, hipertensi, demensia, pembesaran prostat jinak, katarak, dan beragam masalah kejiwaan pada lansia seperti depresi, ansietas, dan gangguan tidur. Kondisi tersebut akan berdampak pada peningkatan kesakitan dan kematian, penurunan kualitas hidup, peningkatan biaya kesehatan, serta kemunculan beragam masalah sosial kemasyarakatan.
Peran remaja dalam pengabdian ini diharapkan dapat meningkatkan keaktifan remaja dalam bidang kesehatan. Terlibatnya remaja dalam pengabdian ini memberikan kedapat memberikan kontribusi yang positif dimasyarakat, serta menumbuhkan sikap peduli remaja terhadap kesehatan. Melalui kegiatan ini juga dapat membantu mengarahkan remaja untuk melakukan kegiatan yang positif, sehingga dapat meminimalisif kegiatan yang negatif di masyarakat

b. Pelaksanaan :

1. Tahap Sosialisasi

Pada tahap ini, akan diadakan penyuluhan tentang pentingnya menjaga kesehatan lahnisa salah, satunya dalam perbaikan pola makan dan life style. Tahap penyusuluhan sosialisasi diadakan di rumah pak dukuh. Peserta berjumlah sebanyak 6 kader dan kader posyandu remaja sebanyak 4 kader. Kami memberikan penyuluhan terkait penyakit degenerative yang sering muncul pada lansia, yaitu asam urat, kolesterol dll. Serta dipaparkan tahapan-tahapan pemeriksaannya. Alat yang digunkan serta cara nya melakukan pemeriksaan. Dalam sosialisasi ini juga dipaparkan terkait proses pemeriksaan dan cara membaca hasil pemeriksaan.

Kami juga menjelaskan bahwa pelatihan kader ini merupakan prosess pemandirian kader untuk lebih mampu dan bias dalam melakukan pengikatan kesehatan di lingkunganya. Dimana mereka mampu melakukan penapisan terkait penyakit yang memang sering diderita lansia,sehingga meminimalisir anka kejadian sakit pada lansia. Dengan demikian taraf kesehatan masyarakat di dusun bogoran trirenggo bantul akan lebih baik.

Sosialisasi yang kami lakukan disertai juga dengan menggunakan power point untuk mempermudah sosialisasi, dan leflet serta panduan pemeriksaan. Dengan metode demikian, kami proses sosialisasi berjalan lancer. 
2. Tahap Pelatihan Pemeriksaan lab

Melakukan praktik secara langsung dengan antara kader yang hadir satu sama lainya serta pemahaman dalam membaca hasil pemeriksaanya.

Hal-hal yang perlu dipersiapkan antara lain,

a. Alat yang digunakan adalah LCD dan layar. Bahan yang digunakan adalah stik hb, stik asam urat, stik glukosa darah, stik koleterol dan alat esay touch CGCU dan GCHb (Persiapan alat sudah tersedia, 2 alat pemeriksaan $\mathrm{GCH}$ dan 2 alat $\mathrm{GCU}$, handscun 2 box, anset, vaccinopen, swab alcohol, tissue, 2 boks strip asam urat, 2 boks strip glukosa darah, 2 strip hb, 2 boks stik kolesterol.

b. Leafleat mengenai penyakit degenerative, dan interprestasi hasil.

c. Pelaksanaan praktik langsung pemeriksaan lab darah

Inilah tahap inti dari kegiatan pengabdian masyarakat yang kami lakukan. Kami beserta kader melakukan latihan pemeriksaan lab. Pelatihan akan dilaksanakan dalam waktu 3 bulan yang dimulai sejak awal didanainya proposal ini. Pelatihan dan Pemantauan akan dilaksanakan setiap 1 bulan sekali dengan alokasi waktu 180 menit setiap pertemuannyam( disesuaikan dengan waktu dilakukanya posyandu lansia)

c. Evaluasi

Melakukan pemantauan/followup terkait dengan keberlanjutan peran kader dalam melakukan pemeriksaan lab ( gula darah, asam urat, hb, dan kolestero) secara mandiri. Hal ini dilakukan selama 3 kali follow up dimana dilakukan di setiap tanggal 18 pada setiap bulannya di posyandu jambu lansia di dusun Bogoran Trirenggo Bantul. Pendampingan tersebut sudah di sepakati sebelumnya untuk melihat ketrampilan dan peran kader dalam pemeriksaan. Kurang lebih proses kunjungan di dusun Bogoran dilakukan sebanyak 7 kali dimulai dari perisinan konsulidasi dengan ketu kader sampai dengan renjana tindak lanjut pendampingan (follow up) saat posyandu lansia, yang dimulai dari perijinan sampai RTL Pengabdian masyarakat, pada bulan September 2017 - Januari 2018. Di mulai dari proses pemberian materi, pelatihan kader, praktik langsung dilakukan saat posyandu lansia berlangsung ( 3 bulan ) dengan pendampingan tim pengabdian.

Proses yang sudah dilalui, kader di dusun Bogoran sangat antusias dan berperan aktif selama pelatihan, dan mandiri melakukan pemeriksaan selama posyandu lansia berlangsung. Kader sangat excaited dengan pelatihan ini dikarenakan berdampak pada kemandirian kader. Dengan etos kerja kader MAU belajar dan harus MAMPU melakukan peningkatan kesehatan di masyarakat salah satunya dengan ketrampilan pemeriksaan darah ini.

\section{Kesimpulan}

Pengabdian Masyarakat "Ibm "PENDEKKAR BIMA" (Pendidikan Kesehatan Kader Dan Remaja Berbasis Masyarakat ) Sebagai Penguatan Kinerja Melalui Pelatihan Pemeriksaan Darah Di Posyandu Jambu Desa Bogoran dapat disimpulkan :

a. Proses penyuluhan dan pelatihan pembuatan tanaman hidroponik berjumlah 10 peserta, yang terdiri dari 7 kader lansia dan 3 kader remaja.

b. Tersedianya media penyuluhan berupa power point, leflet, dan alat GCU Esay touch, masukan strip (hb, asam urat, glukosa, dan kolestrol) .

c. Bertambahnya informasi dan ilmu bagi peserta. Kader sangat excaited dengan pelatihan ini dikarenakan berdampak pada kemandirian kader. Dengan etos kerja kader MAU belajar dan harus MAMPU melakukan peningkatan kesehatan di masyarakat salah satunya dengan ketrampilan pemeriksaan darah ini.

\section{Daftar Pustaka}

Dinas Kesehatan Provinsi Yogyakarta. 2013. Profil Kesehatan Provinsi Yogyakarta Tahun 2014. Yogyakarta : Dinas Kesehatan Provinsi Yogyakarta.

Republika. 2017 (5 mei 2017) diunduh di http://nasional.republika.co.id tanggal 18 Agustus 2017.

Sutikno E. 2011. Hubungan antara Fungsi Keluarga dan Kualitas Hidup Lansia. Med J Indones; 2011 : 2 : 73 - 9.g Studies, 52(11), pp.16781685. 